\title{
PENDEKATAN SISTEM PEMBELAJARAN BAHASA ARAB
}

\author{
Ahmad Munawwir \\ Dosen Pendidikan Bahasa Arab FTK UIN Alauddin Makassar \\ e-mail: ahmad.munawwiruin-alauddin.ac.id
}

DOI: https://doi.org/10.24252/saa.v7i2.11451

\begin{abstract}
Abstrak
Dalam menyukseskan proses pendidikan demi mengembangkan potensi manusia, diperlukan penyusunan standar proses pendidikan, yang dapat dijadikan pedoman oleh setiap guru dalam pengelolaan proses pembelajaran serta menentukan komponen-komponen yang dapat mempengaruhi proses pendidikan. Salah satu pendekatan yang dapat digunakan untuk menentukan kualitas proses pendidikan adalah pendekatan sistem. Pendekatn sistem ini mencakup adanya tujuan, adanya komponen sistem, dan adanya fungsi yang menjamin dinamika (gerak) dan kesatuan kerja sistem. Pembelajaran sebagai suatu sistem yang komponen-komponennya terdiri dari: (1) Peserta didik atau siswa, (2) Guru, (3) Tujuan, (4) Materi, (5) Metode, (6) Sarana/Alat, (7) Evaluasi, dan (8) Lingkungan/konteks. Manfaat pendekatan dalam sistem pembelajaran diantaranya: (1) arah dan tujuan pembelajaran dapat direncanakan dengan jelas, (2) menuntun guru pada kegiatan yang sistematis, (3) dapat merancang pembelajaran dengan mengoptimalkan segala potensi dan sumber daya yang tersedia, (4) dapat memberikan umpan balik.
\end{abstract}

Kata kunci : Pendekatan sistem, komponen pembelajaran

\section{PENDAHULUAN}

Belajar merupakan salah satu faktor yang mempengaruhi dan berperan penting dalam pembentukan pribadi dan perilaku individu, bahkan bagian terbesar perkembangan individu berlangsung melalui kegiatan belajar. Guru sangat berperan penting dalam proses pembelajaran dan proses perubahan tingkah laku siswa. Seorang guru akan berhasil dalam melaksanakan proses pembelajaran jika didukung sistem pembelajaran yang terencana dengan baik. Pendidikan bertujuan untuk mengembangkan potensi manusia, khususnya potensi intelektualnya. Potensi inilah yang dapat dididik untuk dikembangkan ke arah keahlian dan keterampilan. ${ }^{1}$ Melalui sistem pembelajaran yang tersusun secara matang dan sistematis, maka berbagai hambatan yang mungkin akan dihadapi dapat tergambarkan, sehingga dapat menentukan berbagai strategi yang bisa dilakukan untuk mencapai standar proses pendidikan yang diharapkan, hingga tujuan pendidikan itu sendiri dapat tercapai.

Penyusunan standar proses pendidikan diperlukan untuk menentukan kegiatan pembelajaran yang dilakukan oleh guru sebagai upaya ketercapaian Standar Kompetensi Lulusan. Dengan demikian standar proses dapat dijadikan pedoman oleh setiap guru dalam pengelolaan proses pembelajaran serta menentukan komponen-komponen yang dapat mempengaruhi proses pendidikan.

\footnotetext{
${ }^{1}$ Suparlan Suhartono, Filsafat Pendidikan, (Cet. I; Jogjakarta: Ar-Ruzz, 2006), h. 121.
} 
Salah satu pendekatan yang dapat digunakan untuk menentukan kualitas proses pendidikan adalah pendekatan sistem. Melalui pendekatan sistem kita dapat melihat berbagai aspek yang dapat mempengaruhi keberhasilan suatu proses.

Dari uraian di atas, maka penulis dapat merumuskan beberapa permasalahan yaitu sebagai berikut:

1. Apa hakikat pendekatan sistem ?

2. Apa saja komponen dalam sistem pembelajaran?

3. Apa manfaat dari penggunaan pendekatan sistem pembelajaran?

\section{HASIL DAN PEMBAHASAN}

\section{A. Pengertian Pendekatan Sistem Pembelajaran}

Menurut al-Nāqah, Pendekatan (Madkhal al-Tadris/Teaching Approach) ini hakekatnya adalah sekumpulan asumsi tentang proses belajar mengajar, dalam bentuk pemikiran aksiomatis, yang tak perlu diperdebatkan. Dengan kata lain, pendekatan merupakan pendirian filosofis yang selanjutnya menjadi acuan kegiatan belajar dan mengajar bahasa $^{2}$.

Sedangkan istilah sistem adalah suatu konsep yang abstrak, dan meliputi spektrum konsep yang sangat luas. Contohnya saja, seorang manusia, sebuah organisasi, mobil, ataupun susunan tata surya dapat dikategorikan sebagai sebuah sistem. Semua contoh di atas memiliki batasan-batasan tersendiri yang berbeda satu sama yang lain. Namun meskipun demikian, terdapat pula kesamaan dari sisi prosesnya, yaitu adanya masukan dan menghasilkan keluaran. ${ }^{3}$ Oleh karena itu sistem dalam definisi lamanya dinyatakan sebagai seperangkat komponen atau unsur-unsur yang saling berinteraksi untuk mencapai suatu hasil yang diharapkan secara optimal sesuai dengan tujuan yang telah ditetapkan. ${ }^{4}$ Atau sebagaimana definisi yang dipaparkan oleh Harjanto, bahwa sistem adalah suatu gabungan dari komponen-komponen yang terorganisasi sebagai suatu kesatuan, dengan maksud untuk mencapai tujuan yang telah ditetapkan. ${ }^{5}$

Berdasarkan pengertian-pengertian di atas, setidaknya ada tiga hal yang menjadi karakteristik suatu sistem. Pertama, setiap sistem mempunyai ciri utama yaitu mempunyai tujuan. Kedua, setiap sistem memiliki komponen atau unsur-unsur tertentu. Ketiga, setiap sistem memiliki fungsi.

Secara lebih rinci, ciri-ciri yang terkandung dalam sistem atau pendekatan sistem, adalah:

\footnotetext{
h. 34 .

${ }^{3}$ Hamzah B. Uno, Perencanaan Pembelajaran, (Cet. V; Jakarta: PT. Bumi Aksara, 2009), h. 11.

${ }^{4}$ Oemar Hamalik, Perencanaan Pengajaran Berdasarkan Pendekatan Sistem, (Cet.VIII; Jakarta: PT. Bumi Aksara, 2009), h. 1.

${ }^{5}$ Harjanto, Perencanaan Pengajaran, (Cet. I; Jakarta: PT. Rineka Cipta, 1997), h. 44.
}

${ }^{2}$ Mahmud Kamil al-Naqah, Ta'Tim al-Lughah al-'Arabiyyah, (Khurtum; Maktabah Jam'iyyah, 2006), 


\section{Adanya tujuan.}

Setiap rakitan sistem pasti bertujuan, tujuan sistem telah ditentukan lebih dahulu, dan itu menjadi tolok ukur pemilihan komponen serta kegiatan dalam proses kerja sistem. Komponen, fungsi komponen, dan tahap kerja yang ada dalam suatu sistem mengarah ke pencapaian tujuan sistem. Tujuan sistem adalah pusat orientasi dalam suatu sistem.

Kegiatan instruksional pun begitu pula adanya; memiliki tujuan tertentu. Tujuan sebuah lembaga pendidikan adalah untuk memberikan pelayanan pendidikan kepada yang membutuhkan. Tujuan instruksional ialah agar siswa belajar mengalami perubahan perilaku tertentu sesuai dengan tingkatan taksonomi yang telah dirumuskan terlebih dahulu. ${ }^{6}$

\section{Adanya komponen sistem.}

Jika suatu sistem itu adalah sebuah mesin, maka setiap bagian (onderdil) adalah komponen dari mesin (sistemnya); demikian pula halnya dengan pengajaran di sekolah sebagai sistem, maka semua unsur yang tercakup di dalamnya (baik manusia maupun non manusia) dan kegiatan-kegiatan lain yang terjadi di dalamnya adalah merupakan komponen sistem. Jadi setiap sistem pasti memiliki komponen-komponen sistem.

3. Adanya fungsi yang menjamin dinamika (gerak) dan kesatuan kerja sistem.

Tubuh kita merupakan suatu sistem, setiap organ (bagian) dalam tubuh tersebut mengemban fungsi tertentu, yang keseluruhannya (semua fungsi komponen sistem) dikoordinasikan secara kompak, agar diri kita dan kehidupan kita sebagai manusia berjalan secara sehat dan semestinya.

Sistem bukanlah hanya sebagai suatu cara seperti yang banyak dipahami oleh banyak orang selama ini. Cara hanyalah bagian dari rangkaian kegiatan suatu sistem. Yang pasti adalah sistem selalu bertujuan, dan seluruh kegiatan melibatkan dan memanfaatkan setiap komponen yang diarahkan untuk mencapai tujuan tersebut.

Oleh karena suatu sistem merupakan proses untuk mencapai tujuan melalui pemberdayaan komponen-komponen yang membentuknya, maka sistem erat kaitannya dengan perencanaan. Perencanaan adalah pengambilan keputusan bagaimana memberdayakan komponen agar tujuan berhasil dengan sempurna.

Pembelajaran itu sendiri adalah proses, cara, perbuatan menjadikan orang atau makhluk hidup belajar. ${ }^{7}$ Dengan kata lain, pembelajaran adalah upaya menciptakan situasi belajar, atau kegiatan yang bertujuan membelajarkan siswa. ${ }^{8}$ Pembelajaran merupakan sebuah sistem yang bertujuan untuk membantu proses belajar siswa, yang berisi serangkaian peristiwa yang dirancang, disusun sedemikian rupa untuk mempengaruhi dan mendukung terjadinya proses belajar siswa yang bersifat internal.

\footnotetext{
${ }^{6}$ Hamzah B. Uno, Perencanaan Pembelajaran, (Cet. V; Jakarta: PT. Bumi Aksara, 2009), h. 11.

${ }^{7}$ Kamus Besar Bahasa Indonesia, (Cet. I; Jakarta: Balai Pustaka, 2001), h. 17.

${ }^{8}$ Umi Mahmudah, dan Abdul Wahab Rosyidi, Active Learning Dalam Pembelajaran Bahasa Arab, (Cet. I; Malang: UIN-Malang Press, 2008), h. 5.
} 
Pendekatan sistem pada mulanya digunakan di bidang teknik mesin (engineering) untuk merancang sistem-sistem elektronik, mekanik dan militer. Kemudian pendekatan sistem melibatkan sistem manusia mesin, dan selanjutnya dilaksanakan dalam bidang keorganisasian dan manajemen. Pada akhir tahun 1950 dan awal 1960-an mulai diterapkan dalam bidang pendidikan dan pelatihan. ${ }^{9}$

Penerapan pendekatan sistem dalam pembelajaran bukan saja sesuai dengan perkembangan ilmu pengetahuan dan teknologi, tetapi juga sesuai dengan perkembangan dalam psikologi belajar sistematik, yang dilandasi dengan prinsip-prinsip psikologi behavioristik dan humanistik.

Adapun aspek-aspek pendekatan sistem pembelajaran, meliputi aspek filosofis dan aspek proses. Aspek filosofis ialah pandangan hidup yang melandasi sikap si perancang sistem yang terarah pada kenyataan. Sedangkan aspek proses ialah suatu proses dan suatu perangkat alat konseptual. ${ }^{10}$

Gagasan inti dari sistem filosofis itu sendiri adalah suatu sistem merupakan kumpulan dari beberapa komponen, yang saling berinteraksi dan saling bergantung satu sama lain. Oleh karena itu, untuk mengenal suatu sistem, kita harus terlebih dahulu mengenal semua komponen di dalamnya. Perubahan suatu sistem harus pula dilihat dari perubahan komponen-komponen tersebut, karena kita tidak mungkin dapat merubah suatu sistem tanpa merubah sistem tersebut secara menyeluruh. Adapun pendekatan sistem dilihat dari aspek prosesnya merupakan suatu perangkat alat atau teknik. Alat-alat tersebut berbentuk kemampuan (abilitas) dalam:

a. Merumuskan tujuan-tujuan secara operasional;

b. Mengembangkan deskripsi tugas-tugas secara lengkap dan akurat;

c. Melaksanakan analisis tugas-tugas. ${ }^{11}$

Ciri-ciri pendekatan sistem pembelajaran dapat terlihat dari dua ciri utamanya, yakni:

1) Pendekatan sistem sebagai suatu pandangan tertentu mengenai proses pembelajaran dimana berlangsung kegiatan belajar mengajar, terjadinya interaksi antara siswa dan guru, dan memberikan kemudahan bagi siswa untuk belajar secara efektif;

2) Penggunaan metodologi untuk merancang sistem pembelajaran yang meliputi prosedur perencanaan, perancangan, pelaksanaan dan penilaian keseluruhan proses pembelajaran yang tertuju pada konsep pencapaian tujuan pembelajaran. ${ }^{12}$

Oemar Hamalik menambahkan, bahwa terdapat sebuah pola pada pendekatan sistem pembelajaran ini, pola tersebut melalui langkah-langkah sebagai berikut:

1) Identifikasi kebutuhan pendidikan (merumuskan masalah)

\footnotetext{
${ }^{9}$ Oemar Hamalik, Kurikulum dan Pembelajaran, (Cet. XI; Jakarta: PT. Bumi Aksara, 2011), h. 125.

${ }^{10}$ Oemar Hamalik, Kurikulum dan Pembelajaran, (Cet. XI; Jakarta: PT. Bumi Aksara, 2011), h. 125.

${ }^{11}$ Oemar Hamalik, Perencanaan Pengajaran Berdasarkan Pendekatan Sistem, (Cet.VIII; Jakarta: PT. Bumi Aksara, 2009), h. 9.

${ }^{12}$ Oemar Hamalik, Kurikulum dan Pembelajaran, (Cet. XI; Jakarta: PT. Bumi Aksara, 2011), h. 126.
} 
2) Analisis kebutuhan untuk mentransfomasikan menjadi tujuan pembelajaran (analisis masalah)

3) Merancang metode dan materi pembelajaran (pengembangan suatu pemecahan)

4) Pelaksanaan pembelajaran (eksperimental)

5) Menilai dan merevisi. ${ }^{13}$

Dari uraian di atas, dapat penulis rumuskan bahwa untuk mencapai pembelajaran yang efektif dan efisien dibutuhkan pengelolaan komponen pembelajaran secara baik. Dalam pendekatan sistem bahwasanya untuk mencapai tujuan pembelajaran secara maksimal harus didukung dengan komponen pembelajaran yang baik, hingga masing-masing komponen memberikan pengaruh terhadap keberhasilan pembelajaran.

\section{B. Komponen-komponen Pembelajaran}

Dalam pendekatan sistem, pembelajaran merupakan suatu kesatuan dari komponenkomponen pembelajaran yang tidak dapat dipisahkan antara satu dengan yang lain, karena satu sama lain saling mendukung. Komponen-komponen tersebut dapat menunjang kualitas pembelajaran. Sebagaimana yang telah dijelaskan di awal pula bahwa pembelajaran adalah sebuah sistem, artinya suatu keseluruhan dari komponen-komponen yang berinteraksi dan berinteraksi antara satu sama lain dan dengan keseluruhan itu sendiri untuk mencapai tujuan pembelajaran yang telah ditetapkan sebelumnya.

Pembelajaran sebagai suatu sistem yang komponen-komponennya terdiri dari: (1) Peserta didik atau siswa, (2) Guru, (3) Tujuan, (4) Materi, (5) Metode, (6) Sarana/Alat, (7) Evaluasi, dan (8) Lingkungan/konteks. Masing-masing komponen itu sebagai bagian yang berdiri sendiri, namun dalam berproses di kesatuan sistem mereka saling bergantung dan bersama-sama untuk mencapai tujuan. ${ }^{14}$

Kedelapan komponen tersebut rupanya tidak ada satupun komponen yang dapat dipisahkan satu sama lain karena dapat mengakibatkan tersendatnya proses belajar-mengajar. Misalnya pengajaran tidak dapat dilakukan di ruang yang tidak jelas, tanpa siswa, tanpa tujuan, tanpa bahan ajar.

Masing-masing komponen dalam pembelajaran dapat dijelaskan sebagai berikut:

\section{Peserta Didik/Siswa.}

Peserta didik atau siswa merupakan suatu komponen dalam sistem pendidikan, yang selanjutnya diproses dalam proses pendidikan, sehingga menjadi manusia yang berkualitas sesuai dengan tujuan pendidikan nasional. ${ }^{15}$

Siswa adalah individu yang unik, mereka merupakan kesatuan psiko-fisis yang secara sosiologis berinteraksi dengan teman sebaya, guru, pengelola sekolah, pegawai administrasi,

\footnotetext{
${ }^{13}$ Oemar Hamalik, Kurikulum dan Pembelajaran, (Cet. XI; Jakarta: PT. Bumi Aksara, 2011), h. 127.

${ }^{14}$ www.majalahpendidikan.com/blogkabarpendidikan/PendekatanSistemPembelajaranBA/ MajalahPendidikan.htm/diakses pada 03/11/2012.

${ }^{15}$ Oemar Hamalik, Kurikulum dan Pembelajaran, (Cet. XI; Jakarta: PT. Bumi Aksara, 2011), h. 7.
} 
dan masyarakat pada umumnya. Mereka datang ke sekolah telah membawa potensi psikologis dan latar belakang kehidupan sosial. Masing-masing memiliki potensi dan kemampuan yang berbeda. Potensi dan kemampuan inilah yang harus dikembangkan oleh guru.

Dalam pembelajaran bahasa, siswa memiliki porsi yang lebih dari guru. Ini dikarenakan tujuan pembelajaran bahasa adalah mampunya peserta didik menggunakan bahasa kedua selain bahasa ibunya, dan hal ini tak mungkin tercapai kecuali dengan adanya pembiasaan dalam penggunaan bahasa kedua yang tentunya membutuhkan waktu yang tidak sedikit. Seorang guru hanyalah mengarahkan dan memberikan contoh-contoh dan pola-pola yang kemudian dikembangkan oleh siswa itu sendiri.

\section{Guru}

Guru merupakan pemegang peranan utama dalam proses pembelajaran, terlebih lagi dalam proses pembelajaran bahasa. Para siswa tidak mungkin belajar sendiri tanpa bimbingan guru yang mampu mengemban tugasnya dengan baik. Bahkan pada hakikatnya, para siswa hanya mungkin belajar dengan baik jika guru telah mempersiapkan lingkungan positif bagi mereka untuk belajar. ${ }^{16}$

Guru adalah sebuah profesi, oleh karena itu, pelaksanaan tugas guru harus profesional. Pekerjaan guru tidak dapat dilakukan oleh sembarang orang yang tidak memiliki keahlian untuk melakukan kegiatan atau pekerjaan sebagai guru. Walaupun guru sebagai seorang individu yang memiliki kebutuhan pribadi dan memiliki keunikan tersendiri sebagai pribadi, namun guru mengemban tugas mengantarkan anak didiknya mencapai tujuan. Untuk itu guru harus menguasai seperangkat kemampuan yang disebut dengan kompetensi guru.

Seorang guru memiliki banyak tugas, baik yang terikat dengan dinas, ataupun yang dalam bentuk pengabdian. Tugas guru sebagai profesi meliputi mendidik, mengajar, dan melatih. Mendidik berarti meneruskan dan mengembangkan nilai-nilai hidup. Mengajar berarti meneruskan dan mengembangkan ilmu pengetahuan dan teknologi. Sedangkan melatih berarti mengembangkan keterampilan-keterampilan pada siswa. Tugas guru dalam bidang kemanusiaan, di sekolah ia dapat menjadikan dirinya sebagai orang tua kedua. Ia harus mampu menarik simpati sehingga ia menjadi idola bagi siswanya. Bahkan masyarakat menempatkan guru pada tempat yang lebih terhormat di lingkungan karena dari seorang guru diharapkan masyarakat dapat memperoleh ilmu pengetahuan. ${ }^{17}$

Menurut Oemar Hamalik, peran guru adalah sebagai fasilitator, pembimbing, penyedia lingkungan, komunikator, model/contoh yang baik, evaluator, innovator, agen moral dan politik, agen kognitif, dan manager, yang memimpin kelompok siswa dalam kelas sehingga proses pembelajaran berhasil. $^{18}$

Dalam pembelajaran bahasa Arab, seorang guru dituntut untuk menjadi model yang sempurna. Ia dituntut mampu mengucapkan huruf-huruf Hijaiyyah dengan fasih, senantiasa

\footnotetext{
${ }^{16}$ Oemar Hamalik, Perencanaan Pengajaran Berdasarkan Pendekatan Sistem, (Cet.VIII; Jakarta: PT. Bumi Aksara, 2009), h. 43.

${ }^{17}$ Ahmad Sabri, Strategi Belajar Mengajar, Micro Teaching, (Cet. II; Ciputat: PT. Ciputat Press, 2007), h. 66.

${ }^{18}$ Oemar Hamalik, Kurikulum dan Pembelajaran, (Cet. XI; Jakarta: PT. Bumi Aksara, 2011), h. 9.
} 
berbicara dengan bahasa Arab, mengarahkan siswa dalam penggunaan kosa kata dan kalimat dengan pemberian drill-drill, dan senantiasa memotivasi siswa dalam berbahasa Arab.

\section{Tujuan}

Tujuan yang harus dipahami oleh guru meliputi tujuan berjenjang mulai dari tujuan pendidikan nasional, tujuan institusional, tujuan kurikuler, tujuan umum pembelajaran sampai tujuan khusus pembelajaran. Proses pembelajaran tanpa tujuan bagaikan hidup tanpa arah. Oleh sebab itu, tujuan pendidikan dan pembelajaran secara keseluruhan harus dikuasai oleh guru. Tujuan disusun berdasarkan ciri karakteristik anak dan arah yang ingin dicapai.

Pembelajaran bahasa Arab haruslah bertujuan pada kemampuan dan penguasaan siswa terhadap empat kemampuan berbahasa; menyimak (istima'), berbicara (kalam), membaca (qira'ah), dan menulis (kitabah). ${ }^{19}$

\section{Materi}

Materi pembelajaran dalam arti yang luas tidak hanya yang tertuang dalam buku paket yang diwajibkan, akan tetapi mencakup keseluruhan materi pembelajaran. Setiap aktivitas belajar-mengajar harus ada materinya. Anak yang sedang field-trip di kebun menggunakan materi nama-nama tumbuh-tumbuhan, pepohonan, dan buah-buahan. Anak yang praktikum di laboratorium bahasa menggunakan materi muhadașah yang dilakukan langsung oleh orang Arab yang diperdengarkan kepada mereka. Semua materi pembelajaran harus diorganisasikan secara sistematis agar mudah dipahami oleh anak. Materi disusun berdasarkan tujuan dan karakteristik siswa.

\section{Metode}

Metode pembelajaran merupakan cara atau teknik penyampaian bahan pelajaran yang akan digunakan oleh guru pada saat menyajikan bahan pelajaran, baik secara individual maupun secara kelompok. ${ }^{20}$ Metode mengajar ditetapkan berdasarkan tujuan dan materi pembelajaran, serta karakteristik anak. Seorang guru haruslah menguasai beberapa metode, yang memungkinkan dirinya menyesuaikan dengan situasi dan karakteristik siswa, dan tidak terpaku pada satu metode saja.

\section{Sarana/Alat/Media}

Media secara harfiah berarti "perantara" atau pengantar. Menurut Association for Education and Communication Technology (AECH), media ialah segala bentuk yang dprogramkan untuk suatu proses penyaluran inframasi. Sedangkan menurut Education Association, media merupakan benda yang dimanipulasikan, dilhita, didengar, dibaca atau dibicarakan beserta instrument yang dipergunakan dengan baik dalam kegiatan belajar mengajar, dapat mempengaruhi efektifitas program instruksional. ${ }^{21}$

\footnotetext{
${ }^{19}$ Azhar Arsyad, Madkhal Ilā Ṭuruq Ta’Tim al-Lugah al-Ajnabiyyah, (Cet. I; Ujung Pandang: Ahkam, 1998), h. 7.

${ }^{20}$ Ahmad Sabri, Strategi Belajar Mengajar, Micro Teaching, (Cet. II; Ciputat: PT. Ciputat Press, 2007), h. 49.

${ }^{21}$ Ahmad Sabri, Strategi Belajar Mengajar, Micro Teaching, (Cet. II; Ciputat: PT. Ciputat Press, 2007), h. 107.
} 
Agar materi pembelajaran lebih menarik dan mudah dipahami oleh siswa, maka dalam proses pembelajaran digunakan media pembelajaran. Media pembelajaran dapat berupa benda yang sesungguhnya, imitasi, gambar, bagan, grafik, tabulasi dan sebagainya yang dituangkan dalam media. Media itu dapat berupa alat elektronik, alat cetak, dan tiruan. Bahkan penggunaan lingkungan sebagai media pendidikan pun dapat dikategorikan sebagai media. Menggunakan sarana atau alat pembelajaran harus disesuaian dengan tujuan, anak, materi, dan metode pembelajaran.

Penggunaan media dalam pembelajaran bahasa Arab sangat dibutuhkan demi tercapainya tujuan pembelajaran bahasa itu sendiri. Pembelajaran bahasa haruslah menarik,kreatif, inovatif, dan tidak membosankan, hingga tujuan yang diharapkan dapat tercapai, dan salah satu caranya melalui penggunaan media.

\section{Evaluasi}

Secara umum dapat dikatakan bahwa evaluasi pengajaran adalah penilaian/penaksiran terhadap pertumbuhan dan kemajuan peserta didik ke arah tujuan-tujuan yang telah ditetapkan dalam hukum. Hasil penilaian ini dapat dinyatakan secara kuantitatif maupun kualitatif. $^{22}$

Evaluasi dapat digunakan untuk menyusun graduasi kemampuan anak didik, sehingga ada penanda simbolik yang dilaporkan kepada semua pihak. Evaluasi dimaksudkan untuk mengukur dan menilai kemampuan umum peserta didik, dan yang kedua, evaluasi atau ujian dimaksudkan untuk mengukur dan menilai kemampuan individual peserta didik. ${ }^{23}$ dilaksanakan secara komprehensif, obyektif, kooperatif, dan efektif. Dan evaluasi dilaksanakan berpedoman pada tujuan dan materi pembelajaran.

Guru harus melakukan evaluasi terhadap hasil tes dan menetapkan standar keberhasilan. Sebagai contoh, jika semua siswa sudah menguasai kompetensi dasar, maka pelajaran dapat dilanjutkan dengan catatan guru memberikan perbaikan (remidial) kepada siswa yang belum mencapai ketuntasan. Dengan adanya evaluasi, maka dapat diketahui kompetensi dasar, materi, atau individu yang belum mencapai ketuntasan.

\section{Lingkungan}

Lingkungan pembelajaran merupakan komponen pembelajaran yang sangat penting demi suksesnya belajar siswa. Bahkan dalam pembelajaran bahasa peranan lingkungan ini sangatlah signifikan, yang akan sangat membantu proses penguasaan sebuah bahasa. Lingkungan ini mencakup lingkungan fisik, lingkungan sosial, lingkungan alam, dan lingkungan psikologis pada waktu proses pembelajaran berlangsung. Proses pembelajaran bahasa sangatlah tergantung dari pembiasaan, dan hal ini dimulai dari menyimak, melihat, dan memperhatikan hal-hal yang ada di sekitarnya.

Semua komponen pembelajaran harus dikelola sedemikian rupa, sehingga belajar anak dapat maksimal untuk mencapai hasil yang maksimal pula. Mengelola lingkungan pembelajaran baik di kelas maupun di luar kelas bukan merupakan tugas yang ringan. Oleh karenanya guru harus banyak belajar, dan menguasai banyak metode. Siswa membutuhkan

\footnotetext{
${ }^{22}$ Harjanto, Perencanaan Pengajaran, (Cet. I; Jakarta: PT. Rineka Cipta, 1997), h. 277.

${ }^{23}$ hamzah B. Uno, Perencanaan Pembelajaran, (Cet. V; Jakarta: PT. Bumi Aksara, 2009), h. 100.
} 
keterbiasaan sesegera mungkin akan bunyi yang belum familiar bagi mereka. Dalam hal ini guru dituntut untuk dapat mengkondisikan dan menciptakan lingkungan berbahasa bagi siswa, dengan berusaha untuk selalu berbicara dengan bahasa Arab hingga para siswa terbiasa mendengarnya. Pembiasaan ini dapat dimulai dengan hal-hal sederhana seperti menegur mereka dalam bahasa Arab untuk membuka atau menutup jendela. ${ }^{24}$

Adapun menurut Oemar Hamalik, komponen-komponen pembelajaran meliputi tujuh aspek yaitu: (1) tujuan pendidikan dan pengajaran, (2) peserta didik atau siswa, (3) tenaga kependidikan khususnya guru, (4) perencanaan pengajaran sebagai suatu segmen kurikulum, (5) strategi pembelajaran, (6) media pembelajaran, dan (7) evaluasi pembelajaran. ${ }^{25}$

Proses pembelajaran ditandai dengan adanya interaksi antara komponen. Misalnya komponen peserta didik berinteraksi dengan komponen guru, metode/media, perlengkapan/peralatan, dan lingkungan kelas yang mengarah kepada pencapaian tujuan pembelajaran.

\section{Manfaat Pendekatan Sistem Pembelajaran}

Manfaat pendekatan dalam sistem pembelajaran diantaranya :

1. Arah dan tujuan pembelajaran dapat direncanakan dengan jelas.

Perumusan tujuan merupakan salah satu karakteristik pendekatan sistem. Penentuan komponen-komponen pembelajaran pada dasarnya diarahkan untuk mencapai tujuan. Dengan demikian segala usaha baik guru maupun siswa diarahkan untuk mencapai tujuan yang telah ditentukan.

2. Menunt un guru pada kegiatan yang sistematis

Berpikir secara sistem adalah berpikir runtut,sehingga melalui langkah-langkah yang jelas dan pasti memungkinkan hasil yang diperoleh akan maksimal.

3. Dapat merancang pembelajaran dengan mengoptimalkan segala potensi dan sumber daya yang tersedia.

Berpikir sistemis adalah berpikir bagaimana agar tujuan yang telah ditetapkan dapat dicapai oleh siswa. Oleh karena itu setiap guru harus berusaha memanfaatkan seluruh potensi yang relevan yang tersedia.

4. Dapat memberikan umpan balik.

Melalui proses umpan balik dalam pendekatan sistem dapat diketahui apakah tujuan itu telah berhasil dicapai atau belum. Sehingga jika belum berhasil dapat diketahui komponen yang perlu diperbaiki dan kadar perbaikannya.

${ }^{24}$ Lihat: Azhar Arsyad, Bahasa Arab Dan Metode Pengajarannya, (Cet. III; Yogyakarta: Pustaka Pelajar, 2010), h. 68-71.

${ }^{25}$ Oemar Hamalik Perencanaan Pengajaran Berdasarkan Pendekatan Sistem, (Cet.VIII; Jakarta: PT. Bumi Aksara, 2009), h. 77. 


\section{KESIMPULAN}

Dari pemaparan sebelumnya, dapat disimpulkan:

1. Pendekatan hakekatnya adalah sekumpulan asumsi tentang proses belajar mengajar, dalam bentuk pemikiran aksiomatis. Adapun sistem adalah suatu gabungan dari komponen-komponen yang terorganisasi sebagai suatu kesatuan, dengan maksud untuk mencapai tujuan yang telah ditetapkan. Pembelajaran adalah upaya menciptakan situasi belajar, atau kegiatan yang bertujuan membelajarkan siswa. Pendekatan sistem pembelajaran, meliputi aspek filosofis dan aspek proses. Aspek filosofis ialah pandangan hidup yang melandasi sikap si perancang sistem yang terarah pada kenyataan. Sedangkan aspek proses ialah suatu proses dan suatu perangkat alat konseptual. Untuk mencapai pembelajaran yang efektif dan efisien dibutuhkan pengelolaan komponen pembelajaran secara baik. Dalam pendekatan sistem, bahwasanya untuk mencapai tujuan pembelajaran secara maksimal harus didukung dengan komponen pembelajaran yang baik, hingga masing-masing komponen memberikan pengaruh terhadap keberhasilan pembelajaran.

2. Pembelajaran sebagai suatu sistem yang komponen-komponennya terdiri dari: (1) Peserta didik atau siswa, (2) Guru, (3) Tujuan, (4) Materi, (5) Metode, (6) Sarana/Alat, (7) Evaluasi, dan (8) Lingkungan/konteks.

3. Manfaat pendekatan dalam sistem pembelajaran diantaranya: (1) arah dan tujuan pembelajaran dapat direncanakan dengan jelas, (2) menuntun guru pada kegiatan yang sistematis, (3) dapat merancang pembelajaran dengan mengoptimalkan segala potensi dan sumber daya yang tersedia, (4) dapat memberikan umpan balik

\section{DAFTAR REFERENSI}

Arsyad, Azhar. Bahasa Arab Dan Metode Pengajarannya. Cet. III; Yogyakarta: Pustaka Pelajar, 2010.

Hamalik, Oemar. Perencanaan Pengajaran Berdasarkan Pendekatan Sistem. Cet.VIII; Jakarta: PT. Bumi Aksara, 2009.

, Kurikulum dan Pembelajaran. Cet. XI; Jakarta: PT. Bumi Aksara, 2011), h. 125.

Harjanto, Perencanaan Pengajaran. Cet. I; Jakarta: PT. Rineka Cipta, 1997.

Kamus Besar Bahasa Indonesia. Cet. I; Jakarta: Balai Pustaka, 2001.

Mahmudah, Umi. dan Rosyidi, Abdul Wahab. Active Learning Dalam Pembelajaran Bahasa Arab. Cet. I; Malang: UIN-Malang Press, 2008.

al-Nāqah, Mahmud Kamil. Ta'Tim al-Lughah al-'Arabiyyah. Khurtum; Maktabah Jam'iyyah, 2006.

Sabri, Ahmad. Strategi Belajar Mengajar, Micro Teaching. Cet. II; Ciputat: PT. Ciputat Press, 2007. 
Suhartono, Suparlan. Filsafat Pendidikan. Cet. I; Jogjakarta: Ar-Ruzz, 2006.

Uno, Hamzah B. Perencanaan Pembelajaran. Cet. V; Jakarta: PT. Bumi Aksara, 2009.

http://majalahpendidikan.com/blogkabarpendidikan/PendekatanSistemPembelajaranB A/ MajalahPendidikan.htm. 